\title{
Z problematyki początków szkolnictwa średniego w Oświęcimiu
}

Tematyka niniejszego artykułu jest mało znana, ale istotna dla historii oświaty w Oświęcimiu. Chodzi o pierwsze lata istnienia szkoły, która obecnie nosi nazwę Powiatowego Zespołu nr 1 Szkół Ogólnokształcących im. Stanisława Konarskiego w Oświęcimiu. Placówka ta została założona w czasie pierwszej wojny światowej, jest ona zatem najstarszą pełną szkołą średnią w tym mieście. Wprawdzie już w roku 1900 salezjanie założyli w Oświęcimiu gimnazjum, ale stopień zorganizowania tej szkoły był ograniczony: edukacja w niej trwała tylko 4 lata, było to więc tzw. „niższe gimnazjum”. Jednym z inicjatorów i kreatorów ośmioletniego gimnazjum w Oświęcimiu był Feliks (vel Szczęsny) Wincenty Tobiczyk (1861-1925). W wyniku kwerendy udało się ustalić najważniejsze fakty z życia Tobiczyka. Do 2012 roku zarówno dzieje gimnazjum, jak i życiorys jego założyciela były rozpoznane i opisane jedynie w sposób lapidarny ${ }^{1}$. Problem artykułu wplata się w zasady funkcjonowania szkolnictwa średniego w Galicji autonomicznej (1867-1918).

\footnotetext{
${ }^{1}$ Kilka informacji (niezupełnie zgodnych z prawdą) na temat wkładu Feliksa Tobiczyka w założenie gimnazjum w Oświęcimiu zawarto w księdze jubileuszowej, którą opublikowano w 1995 roku. „Właśnie dzięki ogromnym wysiłkom władz miasta, ludzi związanych z Towarzystwem Szkoły Średniej oraz dzięki energii i zaangażowaniu współpracującego z nimi od roku 1914 oświęcimskiego nauczyciela pana Feliksa Tobiczyka, mimo ogromnych trudności finansowych, w 1915 r. nastąpiło otwarcie pierwszej klasy Gimnazjum (Kursy Gimnazjalne istniały już w 1914 r.)". (Z biegiem lat... Wydawnictwo Jubileuszowe z okazji 80-lecia Liceum Ogólnokształcacego im. St. Konarskiego w Oświęcimiu, red. J. Tobiasz, Wrocław-Oświęcim 1995, s. 15-16). W roku 2012 Włodzimierz Liszka wykorzystał efekty poszukiwań badawczych autora niniejszego artykułu, publikując w prasie oświęcimskiej (w numerze wrześniowym „Gońca Kasztelańskiego” oraz w październikowym i listopadowym „Głosu Ziemi Oświęcimskiej”) teksty traktujące o działalności edukacyjnej Feliksa Tobiczyka w Oświęcimiu. W tym samym roku w książce jubileuszowej wydanej przez Powiatowy Zespół nr 1 Szkół Ogólnokształcących im. Stanisława Konarskiego w Oświęcimiu ukazał się tekst popularnonaukowy o erygowaniu pierwszej szkoły średniej w tym mieście. C. Chrząszcz, Nieznane
} 


\section{Szkolnictwo średnie w Galicji}

W monarchii austro-węgierskiej za szkoły stricte średnie uznawano ośmioletnie gimnazja, które miały profil klasyczny (z priorytetową pozycją łaciny i greki w programach szkolnych) lub realny (z dominacją przedmiotów ścisłych i przyrodniczych), oraz siedmioletnie szkoły realne o profilu matematyczno-technicznym bez języków klasycznych ${ }^{2}$. Pełną stabilizacją cieszyły się szkoły utrzymywane przez państwo (tzw. „c.k. zakłady”). Były to do końca XIX wieku placówki przeznaczone wyłącznie dla młodzieży męskiej. Zasady funkcjonowania państwowych szkół średnich w całej monarchii zostały określone w ustawach i rozporządzeniach wiedeńskiego Ministerstwa Wyznań i Oświaty (MWiO), co determinowało przepisy krajowe i regulaminy szkolne. Status prawny i ekonomiczny pełnokwalifikowanej kadry nauczycielskiej szkół państwowych określało c. k. prawodawstwo i realizowało państwo. Elicie tego grona, czyli głównym nauczycielom ,zakładów” przyznano tytuł „profesorów”. Zaliczano ich do IX, VIII lub nawet do VII rangi płatniczej (dyrektorzy mogli także uzyskać VI lub V rangę płatniczą), a ich pracę wynagradzano znakomitym uposażeniem ${ }^{3}$. Zdecydowaną większość nauczycieli gimnazjalnych stanowili tzw. suplenci. Ich niewielkie pobory wypłacano z funduszu krajowego.

Lukratywne posady obejmowali wyłącznie profesorowie szkół utrzymywanych z budżetu państwowego, czyli przez rząd wiedeński. W znacznie trudniejszym położeniu znajdowały się prywatne szkoły średnie. Istnienie w mieście pełnego, ośmioletniego gimnazjum państwowego było marzeniem jego społeczności i miało znaczenie nobilitujące. Wiele miast podejmowało więc we Lwowie poprzez Radę Szkolną Krajową (RSK) i w Wiedniu (władze ministerialne były decydenckie) usilne starania o zgodę na utworzenie tak uposażonych szkół. Najczęściej zabiegi te trwały wiele lat i towarzyszyły im długie negocjacje. Zazwyczaj powoływano w mieście pretendującym do ośrodka gimnazjalnego towarzystwo sympatyków szkoły. Zdesperowani zdobywali się czasem na utworzenie placówki prywatnej. Prowadzenie prywatnego gimnazjum wiązało się jednak z bardzo dużym nakładem finansowym. Taka szkoła nie otrzymywała też od razu praw publicznych. Tzw. ,przywilej publiczności” zdobywała wyłącznie na podstawie decyzji Ministerstwa Wyznań i Oświecenia, którą podejmowano

początki Liceum Konarskiego w Oświęcimiu, [w:] „Na linji startu” - 80 lat później. Jednodniówka Liceum Ogólnokształcącego im. Stanisława Konarskiego w Oświęcimiu, Oświęcim 2012, s. 15-19.

${ }^{2}$ Ustawy i rozporzadzenia obowiąujące w galicyjskich szkołach średnich. Zestawił Henryk Kopia. Odbitka z III tomu ,Zbioru ustaw i rozporządzen administracyjnych”, wydanego pod redakcja Jerzego Piwockiego, Lwów 1900, s. 2-3 i 126.

${ }^{3}$ H. Kramarz, Nauczyciele gimnazjalni Galicji 1867-1914. Studium historyczno-socjologiczne, Kraków 1987, s. 107. 
po przeprowadzeniu szczegółowej lustracji szkoły. Nie wszystkie prywatne gimnazja dostępowały tego przywileju.

3 maja 1909 roku został ułożony statut Towarzystwa Szkoły Średniej w Oświęcimiu4. Głównym celem działalności tej organizacji było podjęcie starań o erygowanie w tym mieście gimnazjum państwowego. Osobą, która ze szczególnym zapałem działała na rzecz utworzenia gimnazjum, był radny Wiktor Leibler - kupiec i właściciel jednego z hoteli w Oświęcimiu.

Kiedy wybuchła pierwsza wojna światowa, wstrzymano wiele inicjatyw założycielskich w dziedzinie oświaty (wojna bowiem zawsze dezintegruje i niszczy szkolnictwo). Na przykład, mimo decyzji, którą podjęło już MWiO, przerwano procedurę upaństwowienia prywatnego gimnazjum w Chrzanowie, o co od kilku lat zabiegało tamtejsze Towarzystwo Szkoły Gimnazjalnej, utrzymujące tę placówkę. Jednakże w Oświęcimiu los był przekorny, bo właśnie działania wojenne przyczyniły się do założenia pierwszej szkoły średniej.

\section{Curriculum vitae Feliksa Tobiczyka}

Powstanie i rozwój tego nietypowego, „wojennego” gimnazjum związany był z osobą jej kierownika, a później dyrektora. Feliks Tobiczyk urodził się 24 maja 1861 roku w Oświęcimiu. W księdze chrztów oświęcimskiej fary zapisano, że jego rodzicami byli Franciszek (z zawodu organista, a także nauczyciel miejscowej szkoły ludowej) i Marcjanna z Klekocińskich ${ }^{5}$. W roku 1880 Feliks ukończył Szkołę Realną w Krakowie. W roku akademickim 1880-1881 studiował na Politechnice (Wyższej Szkole Technicznej) w Wiedniu. W 1882 roku odbył służbę wojskową jako jednoroczny ochotnik. W 1883 roku zdecydował się rozpocząć studia na Wydziale Filozoficznym Uniwersytetu Jagiellońskiego w charakterze tzw. ,studenta nadzwyczajnego"6. Studia o nieregularnym toku zakończył w roku 1894.

Od roku 1887 F. Tobiczyk kierował nauką w ,pierwszorzędnych pensjonatach w Krakowie", a w 1890 roku tworzył „kursy przygotowawcze dla prywatystów do egzaminów w szkołach średnich"s. W roku szkolnym 1893/1894 rozpoczął

\footnotetext{
${ }^{4}$ Archiwum Liceum im. Stanisława Konarskiego w Oświęcimiu. Odpis wierzytelny Statutu Towarzystwa Szkoły Średniej w Oświęcimiu, Oświęcim 3 V 1909.

${ }^{5}$ Archiwum Parafii Rzymskokatolickiej w Oświęcimiu [dalej: APRO], Liber Naturum 1857-1875, t. 4 , s. 55, nr 35 .

${ }^{6}$ Archiwum Uniwersytetu Jagiellońskiego [dalej: AUJ] sygn. S II-472 A. Akta senatu. Rodowody studentów 1883/4, I semestr [Kwestionariusz osobowy Szczęsnego Wincentego Tobiczyka] [b. d.].

${ }^{7}$ AUJ PKEN 26. Państwowa Komisja Egzaminacyjna dla Kandydatów na Nauczycieli Szkół Średnich w Krakowie. Akta egzaminacyjne kandydatów 1868-1939, 1945-1954. Teczka Feliksa Tobiczyka (b. sygn.). [Curriculum vitae Feliksa Tobiczyka], Sambor 10 XII 1905.

${ }^{8}$ Tamże.
} 
pracę nauczycielską - został zastępcą nauczyciela, czyli suplentem w Szkole Realnej w Krakowie. Mieszkał wówczas przy ul. Siemiradzkiego $9^{9}$. Jako suplent pracował w kilku gimnazjach - w roku szkolnym 1900-1901 w Dębicy ${ }^{10}$, od 1902 roku w niemieckojęzycznym gimnazjum w Brodach ${ }^{11}$, a od 1904 roku w Samborze ${ }^{12}$. 1 września 1910 roku rozpoczął pracę w Gimnazjum Realnym w Łańcucie, które w tym dniu zostało upaństwowione ${ }^{13}$.

Aby uzyskać pełniejszy obraz awansu zawodowego Feliksa Tobiczyka, należy przytoczyć kilka ważnych dat w rozwoju jego kariery. 25 stycznia 1894 roku Tobiczyk otrzymał dekret mianowania na zastępcę nauczyciela ${ }^{14}, 4$ grudnia 1909 roku złożył egzamin nauczycielski, uzyskując uprawnienia do nauczania matematyki i fizyki jako przedmiotów głównych w szkołach realnych z polskim językiem wykładowym ${ }^{15}$, a 8 listopada 1910 roku został tzw. „rzeczywistym nauczycielem” ", by trzy lata później, po sfinalizowaniu procedury zwanej „zatwierdzeniem w zawodzie”, uzyskać tytuł profesora. W ten sposób Tobiczyk, zaliczany do grona profesorów łańcuckiego gimnazjum $^{17}$, stał się członkiem najwyżej usytuowanej zawodowo elity galicyjskich nauczycieli szkół średnich. Można przypuszczać, że był on osobą dobrze znaną w środowisku, ponieważ wybrano go członkiem galicyjskiego Zarządu Towarzystwa Nauczycieli Szkół Wyższych ${ }^{18}$.

Rok 1914 okazał się przełomowy dla F. Tobiczyka. Wtedy to na wieść o postępach armii rosyjskiej nacierającej na Galicję i zgodnie z zarządzeniem c.k. władz opuścił on Łańcut i wraz z licznymi uciekinierami udał się na zachód kraju. Celem jego emigracji pierwotnie nie był Oświęcim, lecz Kraków, gdzie spędził 27 lat.

21 września 1914 roku Rosjanie wkroczyli do Łańcuta i pozostali tam aż do 12 maja 1915 roku (z krótką przerwą między 8 października a 5 listopada 1914

${ }^{9}$ XIX. Sprawozdanie Dyrekcji c. k. Wyższej Szkoty Realnej w Krakowie za rok szkolny 1894, Kraków 1894, s. 28.

${ }^{10}$ I. Sprawozdanie Dyrekcyi c. k. Gimnazyum w Dębicy za rok szkolny 1907/08, Tarnów, s. 4.

${ }^{11}$ XXIV. Jahresbericht des k. k. Rudolf-Gymnasiums in Brody 1902, Brody 1902, s. 2 [części urzędowej].

${ }^{12}$ Sprawozdanie Dyrekcyi c. k. Gimnazyum imienia Arcyksiężniczki Elżbiety w Samborze za rok szkolny 1905, s. VI.

${ }^{13}$ I. Sprawozdanie Dyrekcyi c. k. Gimnazyum Realnego w Eańcucie za lata szkolne 1910/1911, Łańcut 1911, s. 16.

${ }^{14}$ „Kalendarzyk Profesorski Tow. Naucz. Szkół Wyższych” 4 (1918), s. 167.

${ }^{15}$ AUJ PKEN 26. Teczka Feliksa Tobiczyka (b. sygn.). Protokót c. k. Komisyi Egzaminacyjnej Krakowskiej dla kandydatów na nauczycieli w gimnazjach $i$ szkołach realnych z egzaminu odbytego $w$ dn. 4 grudnia 1909 r. [b.d., nlb.] Dodatek do spisu nauczycieli szkót średnich w Galicji i na Ślasku zawierający uzupetnienia oraz zmiany, dokonane w ciagu roku 1909, ułożył H. Kopia, Lwów 1910, s. 19.

${ }^{16}$ I. Sprawozdanie Dyrekcyi c. k. Gimnazyum Realnego w Eańcucie za lata szkolne 1910/1911, Łańcut 1911, s. 17.

${ }^{17}$ Szematyzm Królestwa Galicji i Lodomerii z Wielkim Księstwem Krakowskim na rok 1914, Lwów 1914, s. 630.

${ }^{18}$ Tamże, s. 1066. 
roku $)^{19}$. Zagrożenie oblężeniem Krakowa przez armię carską skłoniło władze miasta i komendanta Twierdzy Kraków do ogłoszenia ewakuacji znacznej części mieszkańców. Zmuszono ich do wyjazdu, grożąc procesami przed sądem wojennym i surowymi karami. Od 7 listopada do połowy miesiąca wyjechało z miasta około 60 tys. osób ${ }^{20}$. F. Tobiczyk także opuścił Kraków tuż przed pierwszymi transportami ewakuowanych, tj. w Dzień Zaduszny 1914 roku, i udał się do rodzinnego Oświęcimia.

W księdze meldunkowej obcych w magistracie oświęcimskim zapisano, że Feliks Tobiczyk zatrzymał się w hotelu u wspomnianego wyżej radnego Wiktora Leiblera. Przy okazji zaznaczono, że przybył on z Krakowa, miejscem jego stałego zamieszkania był Łańcut, a hotel opuścił następnego dnia, ale pozostał nadal w Oświęcimiu. Rubryka „imię i nazwisko towarzysza lub towarzyszy podróżnego” pozostała pusta, więc prawdopodobnie podróżował sam ${ }^{21}$.

Jeszcze w tym samym miesiącu zjechały do Oświęcimia rzesze młodzieży z wielu miast galicyjskich. Można przypuszczać, że największą grupę stanowili uczniowie krakowskich państwowych szkół średnich oraz pobliskiego prywatnego gimnazjum w Chrzanowie. Młodzież przybyła do Oświęcimia siłą rzeczy nie kontynuowała nauki, marnując w bezczynności swój intelektualny i moralny potencjał. Ten problem przybrał poważne rozmiary i stał się w mieście zauważalny już w połowie listopada 1914 roku. Osobą, która postanowiła go rozwiązać, był F. Tobiczyk.

\section{Zorganizowanie kursów gimnazjalnych w Oświęcimiu}

Najbardziej znany opis utworzenia pierwszej ośmioklasowej szkoły średniej w Oświęcimiu zawdzięczamy Janowi Rymwidzkiemu, przedwojennemu dyrektorowi gimnazjum. W 1932 roku w publikacji wydanej z okazji poświęcenia nowego gmachu szkoły napisał on:

W 1914 roku, uchodząc przed inwazją rosyjską z Łańcuta, śp. Feliks Tobiczyk przybył do swego rodzinnego miasta Oświęcimia, tu zastał wielu uczniów ze szkół średnich, którzy, jak on rzuceni losem, tracili czas, nie mogąc z powodu zamknięcia zakładów korzystać z nauki.

${ }^{19}$ V. Sprawozdanie Dyrekcyi c. k. Gimnazyum Realnego w Lańcucie za lata szkolne 1914/1916, Łańcut-Jarosław 1916, s. 22.

${ }^{20}$ W. Wróbel, Troska Biskupa Adama Sapiehy o wysiedlonych i uchodźców w latach 1914-1916, Kraków 1999, s. 25.

${ }^{21}$ Archiwum Państwowe w Katowicach Oddział w Oświęcimiu [dalej: APOśw.]. Sygn. MO 60. Ksiega meldunkowa obcych. [T]. (1908-1917), k. 53, nr 23. 
By przyjść tej młodzieży z pomocą, utworzył wspólnie z kilkoma będącymi tu i w okolicy nauczycielami szkół średnich kursy, obejmujące od razu klasy I - VIII, skombinowane tak, że mogli z nich korzystać uczniowie gimnazjów różnego typu ${ }^{22}$.

Skontaktowanie się z nauczycielami szkół średnich, którzy zamieszkali w pobliżu, skonsultowanie z nimi sytuacji, znalezienie choćby prowizorycznego lokalu i przeprowadzenie naboru do nowej placówki wymagało najwyżej kilku tygodni działań, ponieważ Tobiczyk miał już doświadczenie w organizowaniu prywatnych kursów przygotowujących do nauki w szkole średniej ${ }^{23}$. Można więc przypuszczać, że szkoła Tobiczyka rozpoczęła działalność w grudniu 1914 roku. Według J. Rymwidzkiego początkowo zajęcia lekcyjne odbywały się w budynku szkoły ludowej udostępnionym przez władze wojskowe (wcześniej przejętym na koszary) ${ }^{24}$.

W Archiwum Kurii Metropolitalnej w Krakowie przechowywany jest nieznany dotąd list świadka tych wydarzeń. Proboszcz oświęcimski ks. Karol Szałaśny przesłał konsystorzowi biskupiemu prośbę o udzielenie wikaremu, ks. Janowi Wolnemu (nota bene wujowi ks. biskupa Tadeusza Pieronka), tzw. veniam docendi, czyli zezwolenia na nauczanie religii w szkole F. Tobiczyka. Przybliżył przy tym swoim przełożonym genezę powstania nowej placówki edukacyjnej:

Profesorzy szkół średnich środkowej Galicji osiedlili się w Oświęcimiu i założyli dla wygody tutejszej młodzieży prywatne gimnazjum realne w 8 . klasach pod kierownictwem profesora z gimnazjum w Łańcucie Feliksa Tobiczyka.

Kierownik prosił kler parafialny o przyjęcie obowiązków katechetycznych. Podpisany poruczył te obowiązki tymczasowo Imć ks. Janowi Wolnemu.

O czym podpisany w pokorze zawiadamia Najprzewielebniejszy Książęco-B[isku]pi Konsystorz i prosi o odpowiednie zarządzenie ${ }^{25}$.

Ks. K. Szałaśny należał do osób zaangażowanych w życie lokalnej społeczności, a także w rozwój szkolnictwa w powiecie oświęcimskim. W latach

22 „Na linji startu”. Jednodniówka Prywatnego Gimnazjum Koedukacyjnego im. ks. Stanisława Konarskiego w Oświęcimiu wydana z okazji poświęcenia nowego budynku szkolnego dnia dwudziestego listopada tysiąc dziewięćset trzydziestego drugiego roku, Kraków 1932, s. 2.

${ }^{23}$ Jedną z osób, którą Tobiczyk pozyskał do pracy w szkole, był artysta malarz Jan Stankiewicz. Prowadził on zajęcia w placówkach salezjańskich (w szkole zawodowej i w niższym gimnazjum), a ,od roku 1914 uczył w gimnazjum prywatnym w Oświęcimiu [historii] naturalnej i rysunków”. Archiwum Powiatowego Zespołu nr 1 Szkół Ogólnokształcących im. Stanisława Konarskiego w Oświęcimiu [Akta rozproszone] (b. sygn.) [Curriculum vitae Jana Stankiewicza], Oświęcim, 1 III 1920.

${ }^{24}$ „Na linji startu”, s. 2.

${ }^{25}$ Archiwum Kurii Metropolitalnej w Krakowie, Akta szkolne, Koniec XIX w.-1915 (b. sygn.), Ks. Karol Szałaśny do Konsystorza Książęco-Biskupiego w Krakowie, Oświęcim, 2911915. 
w latach 1881-1890 był on nauczycielem religii w elitarnym Gimnazjum Nowodworskiego w Krakowie i katechetą m.in. Stanisława Wyspiańskiego. W Oświęcimiu pełnił funkcję zastępcy przewodniczącego Rady Szkolnej Okręgowej26, był członkiem Rady Miasta oraz zastępcą przewodniczącego Powiatowego Komitetu Narodowego utworzonego w roku 191427. Ks. K. Szałaśny zmarł 9 listopada 1925 roku, a więc cztery miesiące po śmierci F. Tobiczyka. Swój list proboszcz napisał 29 stycznia 1915 roku. Jest to pierwsza pewna data w dziejach oświęcimskiego gimnazjum.

F. Tobiczykowi zależało na upodobnieniu ratio studiorum nowej szkoły do standardów nauczania w szkołach średnich. Rzeczą oczywistą jest, że szukał dla niej katechety. $\mathrm{W}$ powszechnym przekonaniu nauczanie religii w szkołach było konieczne - stanowiło nieodłączny element wychowania młodego pokolenia. Czas powstania szkoły nie sprzyjał jednak pozyskaniu dla niej nauczyciela religii. Trudno się dziwić, że propozycja Tobiczyka kierowana do miejscowych księży nie spotkała się ze spontanicznym entuzjazmem. Pensum obowiązków każdego z nich było wystarczająco obfite, ponieważ oprócz zwykłych zajęć musieli także na przełomie roku podejmować odwiedziny duszpasterskie w domach. Od katechety gimnazjalnego wymagano także wysokich kwalifikacji. Nic więc dziwnego, że w piśmie ks. Szałaśnego znalazło się zastrzeżenie o tymczasowości delegowania ks. J. Wolnego do pracy w szkole.

Rymwidzki określił szkołę założoną przez Tobiczyka mianem „kursów gimnazjalnych". W ramach kursów nie trzeba było realizować pełnego pensum przedmiotów szkolnych przewidzianego dla gimnazjów, nie podlegały też one ścisłej kontroli krajowych władz szkolnych, jakiej poddawane były gimnazja. Relacja ks. K. Szałaśnego wydaje się niemal zbieżna ze słowami J. Rymwidzkiego, zawiera jednak pewne szczegóły, których nie ma we wspomnieniach dyrektora. Ks. Szałaśny określił szkołę Tobiczyka mianem „gimnazjum realnego” i przedstawił konsystorzowi jako pełnowartościową szkołę średnią. Można przypuszczać, że takie zaprezentowanie placówki Tobiczyka miało przekonać władzę kościelną o konieczności przydzielenia do niej katechety. Trzeba pamiętać, że w czasie I wojny światowej konsystorz krakowski miał duże trudności w zapewnieniu nauczania religii nawet w szkołach państwowych. Być może w takim przedstawieniu nowej szkoły pobrzmiewa również osobiste przekonanie byłego katechety gimnazjum św. Anny w Krakowie i radnego Oświęcimia o konieczności utworzenia w tym mieście pełnej szkoły średniej.

${ }^{26}$ Szematyzm Królestwa Galicji i Lodomerii z Wielkim Księstwem Krakowskim na rok 1914, Lwów 1914, s. 692.

${ }^{27}$ Sprawozdania z działalności Powiatowego Komitetu Narodowego za czas od dnia 31 VIII 1914 do dnia 31 V 1915, Oświęcim 1915, s. 3. 
Szkoła Tobiczyka pod względem organizacyjnym miała charakter kursów gimnazjalnych. Tak też nazwano ją w sprawozdaniu dyrektora gimnazjum w Łańcucie ${ }^{28}$. Większość uczęszczających do niej uczniów była oficjalnie przypisana do innych galicyjskich szkół średnich, które na terenach zajętych przez Rosję nie funkcjonowały. W pierwotnym założeniu kierownika kursy były projektem tymczasowym, ukierunkowanym na zaspokojenie doraźnych potrzeb młodzieży, która nagle, w środku roku szkolnego, i wbrew swojej woli pozbawiona została możliwości kontynuowania nauki i znalazła się w Oświęcimiu. W zamierzeniu organizatora kursy miały funkcjonować do momentu wyzwolenia Galicji z rąk Rosjan.

Z całą pewnością szkoła Tobiczyka przestała funkcjonować po kilku miesiącach działalności. Na początku maja 1915 roku, po bitwie pod Gorlicami, inicjatywę na froncie galicyjskim przejęła armia sprzymierzonych państw centralnych. Do końca czerwca wojska rosyjskie zostały wyparte z dużej części terytorium Galicji. Po wakacjach większość uczniów mogła więc kontynuować naukę w swych macierzystych szkołach. Najstarsi uczniowie otrzymali karty mobilizacyjne do wojska (niektórzy zapewne zaciągnęli się do Legionów). RSK wezwała wszystkich profesorów do powrotu do swych macierzystych placówek. W ten sposób pierwsza ośmioletnia szkoła średnia w Oświęcimiu przestała istnieć. Kres działalności placówki Tobiczyka nie zniechęcił jednak lokalnej społeczności do podejmowania starań o szkołę średnią.

\section{Powstanie gimnazjum w Oświęcimiu}

Odtworzenie dalszego ciągu historii gimnazjum to pozornie łatwe zadanie. W protokole posiedzenia oświęcimskiej Rady Miejskiej z 30 czerwca 1915 roku zamieszczono informację o przedłożeniu przez radnego W. Leiblera pisemnej interpelacji „w sprawie starań się o szkołę średnią dla Oświęcimia”29. Miesiąc później burmistrz Roman Mayzel udzielił mu odpowiedzi. Zapewniał o zarządzeniu próbnych wpisów do I klasy i zapowiadał pokrycie kosztów tej rekrutacji z niewykorzystanej kwoty z budżetu na rok $1914^{30}$. Rymwidzki wspominał determinację oświęcimian, starających się latem 1915 roku o założenie gimnazjum:

Jednak zarówno mieszkańcy miasta, jak i okolicznych gmin, widząc wielkim wysiłkiem stworzone gimnazjum w Oświęcimiu, a pragnąc usilnie utrzymać jego istnienie, poczęli nalegać na ś. p.

${ }^{28}$ „Uczyli w innych zakładach podczas inwazji nauczyciele tutejszego zakładu: Tobiczyk Feliks, kierownik kursów gimnazjalnych w Oświęcimiu”, V. Sprawozdanie Dyrekcyi c. k. Gimnazyum Realnego w Eańcucie za lata szkolne 1914/1916, s. 7.

${ }^{29}$ APOśw. Sygn. MO 37, VIII Księga Uchwat Królewskiego Miasta Oświęcimia. Protokót 79 zwyczajnego posiedzenia Rady gminnej królewskiego miasta Oświęcimia z dnia 30 VI 1915, s. 323.

${ }^{30}$ APOśw., Sygn. MO 37, VIII Księga Uchwat Królewskiego Miasta Oświęcimia. Protokót 80 zwyczajnego posiedzenia Rady gminnej królewskiego miasta Oświęcimia z dnia 28 VII 1915, s. 327. 
Tobiczyka, by zakład prowadził dalej, ofiarując mu ze swej strony pomoc. Ulegając prośbom rodziców, utworzył po wakacjach 1915 roku pierwszą klasę, umieszczając ją w wydzierżawionym dla siebie budynku przy ulicy Zatorskiej (dzisiaj Marszałka Piłsudskiego), która to klasa stała się fundamentem dzisiejszego gimnazjum. Z każdym rokiem, kontynuując naukę, tworzył wyższą klasę ${ }^{31}$.

Spis Szkót Średnich Ogólnoksztatcacych Rzeczypospolitej Polskiej opublikowany w 1922 roku przez Ministerstwo Wyznań Religijnych i Oświecenia Publicznego podaje rok 1915 jako datę założenia oświęcimskiego gimnazjum ${ }^{32}$. W tej publikacji podano także informację, że w roku szkolnym 1921/1922 gimnazjum składało się z 7 oddziałów zasadniczych i takiej samej liczby klas. Ta liczba klas wskazywałaby, że szkołę zaczęto organizować w roku $1915^{33}$. Najstarszy zachowany główny katalog (dziennik szkolny) z roku szkolnego 1919/1920 zamieszcza spis uczniów wszystkich klas, które tworzyły oświęcimskie gimnazjum. Rzeczywiście, było w tym roku pięć zespołów klasowych ${ }^{34}$, a zatem pierwszym rokiem jego istnienia powinien być rok 1915. Powyższe świadectwa wskazują na to, że gimnazjum, które było tworzone od podstaw i miało się przekształcić w ośmioletnią szkołę średnią, rozpoczęło działalność pod kierownictwem F. Tobiczyka 1 września 1915 roku.

Istnieją jednak mocne przesłanki źródłowe, które podają w wątpliwość powyższe ustalenia. Po wakacjach roku 1915 F. Tobiczyk nie mógł utworzyć w Oświęcimiu pierwszej klasy gimnazjalnej, ponieważ przez cały rok szkolny 1915/1916 nie było go w tym mieście. Jako profesor państwowej szkoły musiał on powrócić do Łańcuta, by tam pracować. Poczynając od września 1915 roku, Tobiczyk uczył w łańcuckim gimnazjum matematyki i geometrii wykreślnej, otrzymał też od władz szkolnych dwa przywileje - zniżkę godzin i pierwszy dodatek pięcioletni ${ }^{35}$. Od 9 października 1915 do 1 maja 1916 roku zlecono mu pełnienie obowiązków kierownika tej szkoły ${ }^{36}$. Informację o jego awansie zamieszczono w sprawozdaniu szkolnym:

Z początkiem października postanowiono reaktywować gimnazjum w Żółkwi; wobec czego dyrektor gimnazjum łańcuckiego [Kazimierz] Eliasz opuścił Łańcut, oddawszy urzędowanie profesorowi Feliksowi Tobiczykowi, któremu c. k. Rada Szkolna Krajowa poruczyła kierownictwo ${ }^{37}$.

Z wyżej przywołanych względów F. Tobiczyk nie mógł więc w roku szkolnym 1915/1916 osobiście zająć się organizowaniem i kierowaniem gimnazjum

\footnotetext{
${ }^{31}$ „,Na linji startu”, s. 2.

${ }^{32}$ Spis Szkót Średnich Ogólnoksztatcących Rzeczypospolitej Polskiej wedtug stanu z dnia 1 listopada 1921 r., Warszawa 1922, s. 90.

${ }^{33}$ Tamże, s. 90-91.

${ }^{34}$ APOśw., Sygn. LO 342/60, Katalog główny. Rok szkolny 1919/20, s. 2, 41, 64, 87 i 102.

${ }^{35}$ Tamże.

${ }^{36}$ V. Sprawozdanie Dyrekcyi c. k. Gimnazyum Realnego w Lańcucie za lata szkolne 1914/1916, s. 5.

${ }^{37}$ Tamże, s. 23.
} 
w Oświęcimiu. Sporządzony w roku 1924 Spis nauczycieli szkół wyższych, średnich, zawodowych, seminarjów nauczycielskich oraz wykaz zakładów naukowych $i$ władz szkolnych podaje inną datę rozpoczęcia organizowania gimnazjum:

Gimnazjum powstało w r. 1916, obejmując początkowo tylko klasę pierwszą. Stopniowo otwierano klasy wyższe i w 1922/3 r. szkolnym gimnazjum objęło pełnych klas osiem. [...] Stanowisko dyrektora piastuje założyciel od początku istnienia do chwili obecnej ${ }^{38}$.

Zygmunt Zagórowski, redaktor Spisu nauczycieli..., poczynił we Wstępie następującą uwagę: „Wydawnictwo oparto na wiadomościach bezpośrednio dostarczonych przez dyrekcje szkół"39. Autorem wyżej zacytowanej informacji o szkole był więc jej dyrektor F. Tobiczyk lub osoba wyznaczona przez niego.

W pierwszym zdaniu wyżej zacytowanego fragmentu kryje się sprzeczność - jeśli szkoła rzeczywiście powstała w 1916 roku, to wymiar ośmiu klas osiągnęłaby nie w roku 1922/1923, lecz w roku następnym. Aby spróbować wyjaśnić tę antynomię, należy szczegółowo prześledzić informacje o przebiegu kariery zawodowej Tobiczyka w latach 1915-1918. Przeprowadzenie takiej analizy faktów z jego życia może pomóc $\mathrm{w}$ zrozumieniu przyczyn, dla których unikał on podawania precyzyjnej daty powołania do życia swego prywatnego gimnazjum. Kilka wzmianek na temat wydarzeń z życia Tobiczyka po opuszczeniu przez niego Oświęcimia można odnaleźć w dorocznych sprawozdaniach gimnazjów w Łańcucie i Chrzanowie.

J. Rymwidzki napisał, że Tobiczyk postanowił związać swą przyszłość z rodzinnym miastem i założyć w nim szkołę średnią ${ }^{40}$ jeszcze w czasie swego pobytu w Oświęcimiu (a więc w roku szkolnym 1914/1915). Niektóre przesłanki potwierdzają, że rzeczywiście już w tymże roku szkolnym Tobiczyk podjął decyzję o przeniesieniu się na stałe do Oświęcimia. Taki ostateczny zamiar mógł być przyczyną decyzji, jakie podjął po powrocie do Łańcuta. Jak wspomniano wyżej, 9 października 1915 roku Tobiczyk objął funkcję kierownika tamtejszego gimnazjum. Wkrótce jednak wystąpił on do władz szkolnych z prośbą o przyznanie mu urlopu na poratowanie zdrowia. Otrzymał go 16 maja 1916 roku $^{41}$. Następnie dwukrotnie wnosił o przedłużenie czasu urlopowego. Jego podania zostały pozytywnie rozpatrzone 26 września 1916 i 1 lutego $1917 \mathrm{roku}^{42}$.

Wszystko wskazuje na to, że składając wnioski o urlop, Tobiczyk nie zamierzał wracać do pracy w gimnazjum łańcuckim. W wakacje 1916 roku opuścił na

\footnotetext{
${ }^{38}$ Spis nauczycieli szkół wyższych, średnich, zawodowych, seminarjów nauczycielskich oraz wykaz zakładów naukowych i władz szkolnych, red. Z. Zagórowski, Lwów-Warszawa 1924, s. 297.

${ }^{39}$ Tamże, s. III.

40 „Na linji startu”, s. 2.

${ }^{41}$ V. Sprawozdanie Dyrekcyi c. k. Gimnazyum Realnego w Lańcucie za lata szkolne 1914/1916, s. 9.

${ }^{42}$ VI. Sprawozdanie Dyrekcyi c. k. Gimnazyum Realnego w Lańcucie za rok szkolny 1916/17, Łańcut 1917, s. 7.
} 
zawsze Łańcut i udał się do Oświęcimia. W księdze meldunkowej przechowywanej w Archiwum Państwowym w Oświęcimiu zanotowano, że 1 lipca 1916 roku Feliks Tobiczyk, „dyrektor szkoły”, zamieszkał wraz z synem Włodzimierzem i „strycz.” (?) Anną Bobówką w domu, którego właścicielką była niejaka Gawłowa, a który mieścił się przy ul. Zatorskiej ${ }^{43}$.

1 marca 1917 roku, a więc jeszcze w czasie trwania urlopu zdrowotnego, Tobiczyk podjął pracę w prywatnym gimnazjum w Chrzanowie ${ }^{44}$. Uczył tam matematyki i geometrii wykreślnej oraz fizyki w wymiarze 4 godzin tygodniowo ${ }^{45}$. Można przypuszczać, że kierownictwo tej szkoły chętnie zatrudniło wysoko wykwalifikowanego profesora gimnazjum państwowego, ponieważ borykało się wtedy z niedoborem kadr. Dopiero 17 kwietnia 1918 roku Tobiczyk otrzymał od RSK płatny urlop na rok szkolny 1917-1918 i delegację do pracy w prywatnym gimnazjum w Chrzanowie ${ }^{46}$. 7 sierpnia 1918 roku przedłużono mu go na następny rok ${ }^{47}$.

Nietrudno zrozumieć motywację, którą kierował się Tobiczyk, wybierając Chrzanów jako swoje miejsce pracy. RSK mogła mu wydać oficjalną delegację do pracy jedynie w szkole cieszącej się prawami publicznymi. Gimnazjum oświęcimskie nie miało takiego przywileju. Nieduża odległość między Chrzanowem i Oświęcimiem ułatwiała mu w miarę swobodne przemieszczanie się między tymi miastami. Jednocześnie uposażenie profesora państwowego gimnazjum zapewniało mu dostatni byt, więc mógł ograniczyć pensum godzinowe w Chrzanowie do kilku godzin tygodniowo, a resztę czasu poświęcić na kierowanie placówką w Oświęcimiu. Ostatnim rokiem pracy Tobiczyka w Chrzanowie był rok szkolny 1919/192048. W roku następnym gimnazjum oświęcimskie stało się wyłącznym miejscem pracy Feliksa Tobiczyka.

Jak wspomniano wyżej, Spis nauczycieli... z roku 1924 zawiera niejasną sugestię na temat funkcjonowania I klasy gimnazjalnej w Oświęcimiu już w roku szkolnym 1915/1916 (skoro w roku szkolnym 1922/1923 ta placówka osiągnęła liczbę 8 klas, to znaczy, że musiała ona powstać już w roku 1915). Nieobecność Tobiczyka na miejscu w tym roku szkolnym nie wyklucza jego pośredniego udziału w ewentualnej próbie organizowania szkoły już we wrześniu 1915 roku. Albo sam dorywczo angażował

${ }^{43}$ APOśw., Sygn. MO 60, Księga meldunkowa obcych. [T]. (1908-1917), k. 77, nr 39.

${ }^{44}$ VI Sprawozdanie Kierownika Pryw. Gimnazyum Real w Chrzanowie za rok szkolny 1916/17, Chrzanów 1917, s. 9; VII Sprawozdanie Kierownika Pryw. Gimnazyum Real. w Chrzanowie za rok szkolny 1917/18, Chrzanów 1918, s. 5.

${ }^{45}$ VI Sprawozdanie Kierownika Pryw. Gimnazyum Real. w Chrzanowie za rok szkolny 1916/17, Chrzanów 1917, s. 9.

${ }^{46}$ VII Sprawozdanie Kierownika Pryw. Gimnazyum Real w Chrzanowie za rok szkolny 1917/18, Chrzanów 1918, s. 6.

${ }^{47}$ VIII. Sprawozdanie Dyrekcyi Państwowego Gimnazyum Realnego w Łańcucie za rok szkolny 1918/19, Łańcut 1919, s. 9.

${ }^{48}$ Archiwum I Liceum Ogólnokształcącego im. Stanisława Staszica w Chrzanowie. Katalog główny 1919/20 (b. sygn.). [Nlb]. 
się $\mathrm{w}$ tę sprawę jeszcze przed powrotem do Łańcuta, albo pozostawił aktywowi nauczycielskiemu lub społecznikowskiemu szczegółowe instrukcje i wytyczne odnośnie do założenia pierwszej prowizorycznej klasy.

W pierwszych miesiącach funkcjonowania (w roku szkolnym 1915/1916) placówka ta nie spełniała jednak formalnych warunków koniecznych do tego, by władze oświatowe mogły ją uznać za szkołę średnią. Po przybyciu do Oświęcimia w 1916 roku Tobiczyk zapewne przejął kierownictwo powstającej placówki i zajął się systematycznym organizowaniem jej działalności. Jeśli weźmie się pod uwagę powyższe okoliczności, to wówczas zrozumiałe staje się datowanie założenia szkoły przez samego Tobiczyka właśnie na rok 1916.

Przez pierwsze lata istnienia (1915-1918) gimnazjum oświęcimskie było zatem placówką in statu nascendi. Być może właśnie z powodu skromnych początków działalności szkoły nie wzmiankowano o niej w „Kalendarzyku Profesorskim” z 1918 roku oraz w nieformalnym spisie szkół średnich sporządzonym przez RSK 19 września 1918 roku $^{49}$.

Rymwidzki w Jednodniówce opisał krótko dzieje szkoły w pierwszych latach nowego okresu historycznego (po odzyskaniu przez Polskę niepodległości). Według niego do 1919 roku była ona jedynie prywatną własnością dyrektora, a jej źródłem utrzymania było czesne, które wpłacali rodzice na ręce jej kierownika i właściciela ${ }^{50}$. Taki system finansowania stał się przyczyną dramatycznej sytuacji materialnej, w jakiej znalazła się szkoła w 1919 roku. Rok szkolny 1919/1920 okazał się przełomowy w dziejach gimnazjum. Uzyskało ono wówczas prawa placówki publicznej i przeszło na własność Towarzystwa Szkoły Średniej w Oświęcimiu ${ }^{51}$. Stało się to podstawą jej stabilizacji finansowej i dalszego rozwoju w ciągu dwudziestu lat niepodległej Rzeczypospolitej. Feliks Tobiczyk kierował gimnazjum aż do swej śmierci 30 czerwca 1925 roku $^{52}$.

$*$

Kwerenda dostępnych źródeł pozwala stwierdzić, że powstanie pierwszej pełnej szkoły średniej w Oświęcimiu nie było jednorodnym aktem ustawowym, lecz następowało etapami. Nie istnieje zatem jedna konkretna data erygowania szkoły. Przytoczone w niniejszym artykule materiały źródłowe zdają się dowodzić, że oświęcimskie gimnazjum miało aż trzy początki swej egzystencji: grudzień 1914 roku (początek procesu kreacyjnego - założenie kursów gimnazjalnych), wrzesień

${ }^{49}$ Centralnyj Derżawnyj Istoryčnyj Archiv Ukrainy u L'vovi, Akta Rady Szkolnej Krajowej oraz szkół średnich z lat 1867-1918, fond 178, opis 3, sprawa 315, Rada Szkolna Krajowa do Biura Krajowego Powszechnego Zakładu Pensyjnego dla Funkcjonariuszy, [Lwów], 19 IX 1918, k. 4-5.

${ }^{50}$ „Na linji startu”, s. 2-3.

${ }^{51}$ Tamże, s. 3.

${ }^{52}$ Feliks Tobiczyk umarł jako wdowiec po Eugenii z Gryglewskich. APRO, Liber Mortuorum $1894-1933$, t. 4 , s. 302 , nr 40. 
1915 roku (ogłoszenie naboru do I klasy gimnazjalnej) oraz wrzesień 1916 roku (przejęcie szkoły pod bezpośrednie kierownictwo F. Tobiczyka). Chronologicznie pierwszą pewną datą w dziejach szkoły jest dzień 29 stycznia 1915 roku. Wówczas to proboszcz miejscowej parafii zwrócił się do Konsystorza Książęco-Biskupiego w Krakowie z prośbą o udzielenie veniam docendi pierwszemu katechecie gimnazjum.

Pierwsza szkoła średnia w Oświęcimiu niebawem będzie obchodzić setną rocznicę swego istnienia. Odegrała ona niebagatelną rolę kulturotwórczą w lokalnym środowisku. Stała się ważnym miejscem kształcenia i wychowywania elity miejscowej społeczności. Kontynuowanie badań na temat dziejów tej placówki wydaje się bardzo ciekawym wyzwaniem, pozostaje więc mieć nadzieję, że ciąg dalszy studiów nad dziejami tej szkoły nastąpi.

\section{Summary}

\section{From the problematic aspects of the beginnings of secondary education in Oświęcim}

The article reconstructs the events connected with the beginning years of the grammar school in Oświęcim (today's Konarski Secondary School). The work of Feliks Tobiczyk, the founder of the school who came from Oświęcim and was a professor in the grammar school in Łańcut, is also reconstructed in the article.

The foundation of the grammar school in Oświęcim had a few stages. At the beginning (presumably in December 1914) the grammar school courses were set up in order to satisfy the temporary needs of a huge number of pupils who were escaping from the Russian and left their home schools. $29^{\text {th }}$ January 1915 is the first certain date in the history of the courses. On that day fr. Karol Szałaśny, the parish priest in Oświęcim, sent a letter (which was discovered by the author of the article) to the consistory in Kraków asking them to assign a religion teacher to the school headed by Tobiczyk.

The success of the grammar school courses as well as the appeals of the local community made Tobiczyk decide to found a full secondary school in Oświęcim. He devoted himself to the foundation of the school in September 1916 and headed it at his own cost until 1919. Then the school was taken over by Secondary School Society in Oświęcim.

\section{Keywords}

People: Feliks Tobiczyk, Rev. Karol Szałaśny, Jan Rymwidzki, Roman Mayzel, Wiktor Leibler

Subjects: High school courses in Oświęcim, Private Real High School in Oświęcim, World War I, School National Council

Geographical names: Galicja, Oświęcim, Kraków, Łańcut, Chrzanów 
